Check for updates

Cite this: RSC Adv., 2017, 7, 20732

Received 3rd January 2017 Accepted 4th April 2017

DOI: $10.1039 / c 7 r a 00066 a$

rsc.li/rsc-advances

\title{
A contact study in hole conductor free perovskite solar cells with low temperature processed carbon electrodes $\dagger$
}

\begin{abstract}
J. Li, ${ }^{\text {ab }}$ J. X. Yao, ${ }^{b}$ X. Y. Liao, ${ }^{\text {bc }}$ R. L. Yu, ${ }^{b}$ H. R. Xia, (D) ${ }^{a b}$ W. T. Sun (D) ${ }^{\text {bc }}$ and L. M. Peng ${ }^{\star a b}$
Hole conductor material (HTM) free photovoltaic devices with graphite electrodes were fabricated at low temperature. An $\mathrm{FTO} /$ perovskite contact and $\mathrm{TiO}_{2}$ /graphite contact were investigated. The results suggest that the carrier recombination processes resulting from $\mathrm{FTO} /$ perovskite and $\mathrm{TiO}_{2} /$ carbon contacts affect the device performance greatly. By optimization, a $65 \mathrm{~nm} \mathrm{TiO}_{2}$ compact layer with a $380 \mathrm{~nm} \mathrm{TiO}_{2}$ mesoporous layer can efficiently decrease the contact between FTO and perovskite materials. The contact between $\mathrm{TiO}_{2}$ and graphite was lowered by the improvement of perovskite coverage. The photo-voltages were enhanced from $0.695 \mathrm{~V}$ to $0.820 \mathrm{~V}$ and a best efficiency of $10.4 \%$ was obtained.
\end{abstract}

\section{Introduction}

Being renewable and clean, solar energy is very promising to substitute fossil energy in the future. Photovoltaic devices can be used to convert solar energy to electricity directly. A low cost and high photo-electrical conversion efficiency (PCE) has always been the goal for photovoltaic device research. Perovskite solar cells (PSCs) based on mixed organic-inorganic halide perovskites $\mathrm{ABX}_{3}\left(\mathrm{~A}=\mathrm{CH}_{3} \mathrm{NH}_{3}(\mathrm{MA})\right.$ or $\mathrm{NH}_{2} \mathrm{CHNH}_{2}$ (FA), B $=\mathrm{Pb}$ or $\mathrm{Sn}, \mathrm{X}=\mathrm{Cl}, \mathrm{Br}$, I or mixed halides) were just in line with the requirements of low cost and high efficiency, and have attracted a lot of attention from scientists all around the world since 2009. ${ }^{1-16}$ At this point in time, PSCs have reached an efficiency of over $20 \% .^{2}$

Perovskite photovoltaic devices were based on the structure of dye sensitized solar cells at first, ${ }^{3-6}$ then it was found that perovskite can act as both an electron and hole transport layer itself, and devices based on a planar structure appeared..$^{7-13}$ In these structures, TCO and HTM are the most expensive components $^{\mathbf{1 4}}$ and the HTM layer is even less conductive than perovskite materials themselves. For these reasons, some scientists tried to use carbon-based materials to dope or replace

${ }^{a}$ Academy for Advanced Interdisciplinary Studies, Peking University, Beijing 100871, China.E-mail: lmpeng@pku.edu.cn

${ }^{b}$ Key Laboratory for the Physics and Chemistry of Nanodevices, Department of Electronics, Peking University, Beijing 100871, China. E-mail: wtaosun@pku.edu.cn ${ }^{c}$ School of Software and Microelectronics, Peking University, Beijing 100871, China $\dagger$ Electronic supplementary information (ESI) available: Fig. S1-S9: cross-sectional SEM images of $\mathrm{TiO}_{2}$ compact and mesoporous layers, schematic structure of perovskite materials and the corresponding XRD pattern, $J-V$ curves of a device with carbon on pure $\mathrm{TiO}_{2}$, hysteresis effects, photo-stability of the PSCs, photographs and corresponding photovoltaic parameters of PSCs by water-corrosion. See DOI: 10.1039/c7ra00066a the HTMs. ${ }^{15,16}$ Moreover, other researchers turned their attention toward TCO free ${ }^{17-19}$ and HTM free ${ }^{20-37}$ perovskite solar cells.

In HTM free structure, graphite materials were often used as counter electrodes because as a resource they were easily accessible, cheap and stable. ${ }^{24-37}$ Han's group have carried out some pioneering work with graphite electrodes, ${ }^{28-31}$ adopting a high temperature $\left(400{ }^{\circ} \mathrm{C}\right)$ processed graphite electrode and then dipping perovskite materials into the device. In order to reduce electrical leakage, a thick barrier layer $\left(1 \mu \mathrm{m} \mathrm{ZrO}_{2}\right)$ was introduced on the $\mathrm{TiO}_{2}$ mesoporous layer. The device efficiency of this structure has reached to about $15 \% .{ }^{33}$ However, the thick barrier layer $\left(\mathrm{ZrO}_{2}, \mathrm{Al}_{2} \mathrm{O}_{3}\right.$, etc. $)$ in this structure may introduce a high series resistance, some scientists were then focused on devices without the thick barrier layers. To solve the electrical leakage problem, low temperature processed graphite electrodes were introduced in the new structure which could then be printed after the perovskite was loaded into $\mathrm{TiO}_{2},{ }^{35-37}$ so that finally an efficiency of $13.5 \%$ was obtained. ${ }^{37}$ The HTM free PSCs device structure with low temperature processed graphite electrodes is illustrated in Fig. 1a. Fig. 1b is the corresponding a)

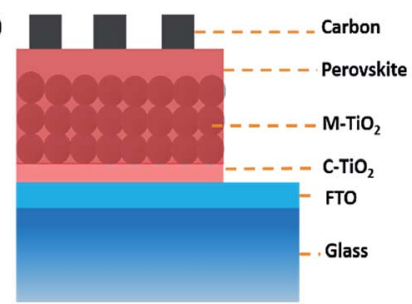

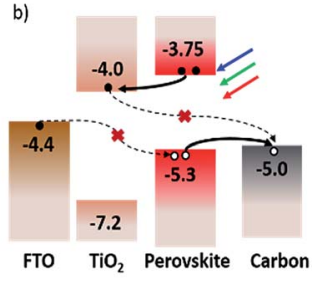

Fig. 1 (a) A schematic structure of the perovskite solar cell device and (b) the corresponding energy band diagram and the carrier transport process. 
energy band diagram. The carrier transport processes show that photo-induced carriers can be separated by perovskite/ $/ \mathrm{TiO}_{2}$ heterojunction but might be recombined at FTO/perovskite and $\mathrm{TiO}_{2} /$ carbon contact area, which may affect the device performance greatly. However, there were few research papers reporting the contact effects on performances of HTM free PSCs.

Here, we fabricated HTM free perovskite solar cells with low temperature graphite electrodes. We then investigated the effects of $\mathrm{FTO} /$ perovskite and $\mathrm{TiO}_{2}$ /graphite contacts on the device's performances. By optimization, the photo-voltage was improved from $0.695 \mathrm{~V}$ to $0.820 \mathrm{~V}$ with an improvement of $18 \%$ and an efficiency of $10.4 \%$ was finally obtained.

\section{Experimental section}

\section{Materials}

All reagents and solvents were used as received. Tetrabutyltitanate, anhydrous ethanol, diethanolamine, $\mathrm{TiO}_{2}$ paste (Dyesol 18NRT), $\mathrm{PbCl}_{2}$ (99.999\%, Alfa Aesar), $\mathrm{CH}_{3} \mathrm{NH}_{3} \mathrm{I}$ (99.9\%, HeptaChroma), anhydrous $N^{\prime}, N$-dimethylformamide (DMF, $99.8 \%$, Super Dry, J\&K), graphite paste (Guangzhou Seaside Technology Co., Ltd), FTO glasses ( $8 \Omega \square^{-1}$, HeptaChroma).

\section{Preparation of $\mathrm{TiO}_{2}$ layers}

FTO glasses was sonically cleaned by acetone, ethanol and deionized water for 15 minutes, respectively, after dried by nitrogen gun, the FTO glasses were treated by $\mathrm{UV}-\mathrm{O}_{3}$ for 15 minutes. The $\mathrm{TiO}_{2}$ compact precursor dispersion was prepared by mixing $22.6909 \mathrm{~g}$ tetrabutyltitanate, $89.068 \mathrm{~g}$ anhydrous ethanol, $2.8 \mathrm{~g}$ deionised water and $7.01 \mathrm{~g}$ diethanolamine together and stirring for 24 hours. We then let the dispersion stand for 24 hours. Then the dispersion was spin-coated on FTO at different speed $(4000,5000,6000,7000,8000 \mathrm{rpm})$ and heated in an oven at $500{ }^{\circ} \mathrm{C}$ for 2 hours (the heating rate was $2{ }^{\circ} \mathrm{C} \mathrm{min}^{-1}$ ). After they had cooled down to room temperature, mesoporous $\mathrm{TiO}_{2}$ layer was deposited on the substrates by spincoating a commercial $\mathrm{TiO}_{2}$ paste (Dyesol 18NRT, Dyesol) diluted in ethanol $\left(1 \mathrm{~g} \mathrm{TiO}{ }_{2}\right.$ paste in $3.5 \mathrm{~g}$ ethanol $)$ at various speed $(1500,2000,3000,4000,6000 \mathrm{rpm})$ and finally heated in an oven at $500{ }^{\circ} \mathrm{C}$ for 30 minutes (the heating rate was $2{ }^{\circ} \mathrm{C} \mathrm{min}{ }^{-1}$ ).

\section{Fabrication of photovoltaic devices}

The perovskite precursor solution with different concentrations (13.2 wt \%, $26.4 \mathrm{wt} \%, 44.3 \mathrm{wt} \%, 51.5 \mathrm{wt} \%)$ were made by dissolving $\mathrm{CH}_{3} \mathrm{NH}_{3} \mathrm{I}$ and $\mathrm{PbCl}_{2}(3: 1 \mathrm{M}$ ratio) into DMF, which were stirred at $60{ }^{\circ} \mathrm{C}$ overnight. For instance, $51.5 \mathrm{wt} \%$ solution contains $0.636 \mathrm{~g} \mathrm{CH}_{3} \mathrm{NH}_{3} \mathrm{I}$ and $0.371 \mathrm{~g} \mathrm{PbCl}$ in $1 \mathrm{ml}$ DMF. After the solution cooled to room temperature, the solution was filtered twice using a $0.45 \mu \mathrm{m}$ pore PVDF syringe filter. Then the solution was spin-coated on $\mathrm{TiO}_{2}$ substrate at a speed of $3000 \mathrm{rpm}$ for $30 \mathrm{~s}$ and then heated at $110{ }^{\circ} \mathrm{C}$ for 45 minutes on a hotplate, all these process was carried out under Ar atmosphere $\left(\mathrm{O}_{2}\right.$ and $\left.\mathrm{H}_{2} \mathrm{O}<1 \mathrm{ppm}\right)$. After that, the samples were taken out to ambient atmosphere and a layer of graphite paste was quickly printed on perovskite layer by doctor-blading method, which is heated at $100{ }^{\circ} \mathrm{C}$ for 15 minutes then. The thickness of graphite electrodes were controlled by using a $10 \mu \mathrm{m}$ thick tape. Then they were heated at $100{ }^{\circ} \mathrm{C}$ for 15 minutes on a hotplate. Finally the electrodes were extracted by pressing copper tapes on graphite with clamps.

\section{Characterization}

A field-emission scanning electron micrograph (SEM) at an acceleration voltage of $20 \mathrm{kV}$ were used to characterize the surface morphology of perovskite film and thickness of $\mathrm{TiO}_{2}$ film (FEI Quanta 600 microscope). X-ray diffraction patterns were carried out by a Bruker-AXS Micro diffractometer (model D5005). UV-vis transmittance spectra were recorded by an UV-vis Spectrophotometer and the wavelength varied from $350 \mathrm{~nm}$ to $800 \mathrm{~nm}$ (UV 5000 spectrometer, Cary). $J-V$ curves and the stabilized-power output curve were measured by an electrochemical workstation (CHI660c) under $100 \mathrm{~mW} \mathrm{~cm}{ }^{-2}$ illumination (AM $1.5 \mathrm{G}$ ) by a solar simulator (300 W Oriel Solar Simulator Model, 91160). For the $J-V$ measurement, the voltage step and scan rate were $1 \mathrm{mV}$ and $0.1 \mathrm{~V} \mathrm{~s}^{-1}$, respectively. The backward scanning started from $-1 \mathrm{~V}$ (over the open-circuit photo voltage) to $0 \mathrm{~V}$ (the short-circuit condition) and the forward scanning started from $0 \mathrm{~V}$ to $-1 \mathrm{~V}$. For stabilized-power output measurement, the bias voltage was $-0.6 \mathrm{~V}$ and the lasting time is 400 seconds. The illuminated area of the device was $3 \mathrm{~mm} \times 3 \mathrm{~mm}$ controlled by a metal mask. Incidentphoton-to-current conversion efficiency (IPCE) was measured by using an IPCE system (Newport).

\section{Results and discussion}

To investigate the $\mathrm{FTO} /$ perovskite contact, $\mathrm{TiO}_{2}$ compact $\left(\mathrm{C}-\mathrm{TiO}_{2}\right)$ and $\mathrm{TiO}_{2}$ mesoporous $\left(\mathrm{M}-\mathrm{TiO}_{2}\right)$ layers with different thickness were prepared on FTO substrates. C-TiO ${ }_{2}$ layers were spin-coated on FTO at varing speeds. The sectional SEM images of $\mathrm{C}-\mathrm{TiO}_{2}$ layers with different thickness were shown in Fig. $\mathrm{S} 1, \dagger$ showing that the thickness of $\mathrm{C}-\mathrm{TiO}_{2}$ layer increased from about $35 \mathrm{~nm}, 45 \mathrm{~nm}, 60 \mathrm{~nm}, 65 \mathrm{~nm}$ to $80 \mathrm{~nm}$ with the speed decreasing from $8000,7000,6000,5000$ to $4000 \mathrm{rpm}$. Perovskite materials and graphite electrode were then prepared on the C-TiO ${ }_{2}$ layers to assemble the photovoltaic devices. Afterwards, the linear sweep voltammetry measurement of the devices were carried out. The $J-V$ curves under illumination are presented in Fig. 2a and the corresponding photovoltaic parameters are
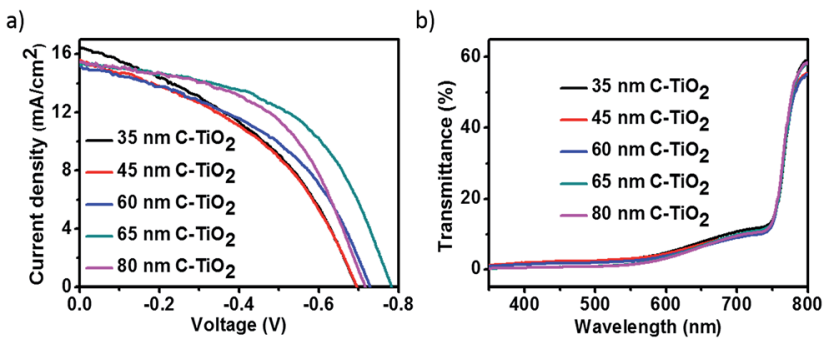

Fig. 2 (a) $J-V$ curves and (b) transmittance curves of perovskites on various thickness $\mathrm{C}-\mathrm{TiO}_{2}$ under illumination. 
shown in Table 1 . The shunt resistance $\left(R_{\mathrm{sh}}\right)$ and series resistance $\left(R_{\mathrm{S}}\right)$ were calculated from $J-V$ curves as reported previously. ${ }^{38}$ The value of $R_{\mathrm{s}}$ could be determined by the following equation:

$$
-\frac{\mathrm{d} V}{\mathrm{~d} J}=\frac{A K_{\mathrm{B}} T}{e}\left(J_{\mathrm{sc}}-J\right)^{-1}+R_{\mathrm{s}}
$$

where $V$ is the bias voltage applied to the device, $J$ is the current density, $A$ is the diode ideality factor, $K_{\mathrm{B}}$ is the Boltzmann constant, $T$ is temperature, and $e$ is the elementary charge. $R_{\mathrm{S}}$ can be obtained from a linear fitting of $-\mathrm{d} V / \mathrm{d} J v s .\left(J_{\mathrm{sc}}-J\right)^{-1}$. The value of $R_{\mathrm{sh}}$ could be determined by the following equation:

$$
-\frac{\mathrm{d} V}{\mathrm{~d} J}=R_{\mathrm{sh}}
$$

The equation is applicable when $V$ is near 0 . The $V_{\text {oc }}$ of these devices increased from $0.695 \mathrm{~V}$ to $0.784 \mathrm{~V}$ as $\mathrm{C}^{-T i O}{ }_{2}$ layer thickness increased from $35 \mathrm{~nm}$ to $65 \mathrm{~nm}$, and the shunt resistances improved from $114 \Omega \mathrm{cm}^{2}$ to $296 \Omega \mathrm{cm}^{2}$. The $J_{\mathrm{sc}}$ of these devices didn't greatly change, which may attributed to the similar light transmittance characters as shown in Fig. 1b. The results indicate a reduction of $\mathrm{FTO} /$ perovskite contact area with thicker $\mathrm{C}^{-} \mathrm{TiO}_{2}$ layers. When the thickness of $\mathrm{C}-\mathrm{TiO}_{2}$ layer further increased to $80 \mathrm{~nm}$, there were some visible particles in the film, which resulted in a lower performance of the device. The device with $60 \mathrm{~nm}$ thick $\mathrm{C}^{-} \mathrm{TiO}_{2}$ layer showed the best performance with the photoelectrical efficiency of $6.3 \%, J_{\mathrm{sc}}$ of $15.3 \mathrm{~mA} \mathrm{~cm}^{-2}, V_{\mathrm{oc}}$ of $0.784 \mathrm{~V}$ and $\mathrm{FF}$ of 0.53 . In order to further decrease $\mathrm{FTO} /$ perovskite contact, $\mathrm{M}$ - $\mathrm{TiO}_{2}$ layers with different thickness were coated onto $60 \mathrm{~nm} \mathrm{C}-\mathrm{TiO}_{2}$ layer.

$\mathrm{M}-\mathrm{TiO}_{2}$ layers were also prepared by spin-coating with different speed. Fig. S2 $\uparrow$ presents the cross-sectional SEM images of $\mathrm{M}^{-} \mathrm{TiO}_{2}$ layers, with thickness varing from $160 \mathrm{~nm}$, $260 \mathrm{~nm}, 380 \mathrm{~nm}, 450 \mathrm{~nm}$ to $480 \mathrm{~nm}$. Different photovoltaic devices were then fabricated using $\mathrm{M}-\mathrm{TiO}_{2}$ layers of various thickness. $J-V$ curves under illumination and detail parameters of the devices are recorded in Fig. 3a and Table 2, respectively. It can be seen that the performance improved greatly after the introduction of $\mathrm{M}^{-\mathrm{TiO}_{2}}$ layers. Compared with devices on C-TiO 2 layer, the $V_{\text {oc }}$ of devices on $\mathrm{M}-\mathrm{TiO}_{2} / \mathrm{C}-\mathrm{TiO}_{2}$ improved from $0.695-0.784 \mathrm{~V}$ to $0.790-0.817 \mathrm{~V}$, and the shunt resistance increased from $114-296 \Omega \mathrm{cm}^{2}$ to $340-577 \Omega \mathrm{cm}^{2}$. The enhanced performances suggested that FTO/perovskite contact area was further decreased by adding a $\mathrm{TiO}_{2}$ mesoporous layer. The $J_{\mathrm{sc}}$ of devices with $\mathrm{M}-\mathrm{TiO}_{2}$ showed a slight decrease with $\mathrm{M}-\mathrm{TiO}_{2}$

Table 1 Photovoltaic parameters of the perovskite solar cells with

\begin{tabular}{|c|c|c|c|c|c|c|}
\hline $\mathrm{C}-\mathrm{TiO}_{2}$ & $\begin{array}{l}J_{\mathrm{sc}} \\
\left(\mathrm{mA} \mathrm{cm}^{-2}\right)\end{array}$ & $V_{\mathrm{oc}}(\mathrm{V})$ & $\mathrm{FF}$ & $\eta(\%)$ & $\begin{array}{l}R_{\mathrm{s}} \\
\left(\Omega \mathrm{cm}^{2}\right)\end{array}$ & $\begin{array}{l}R_{\mathrm{sh}} \\
\left(\Omega \mathrm{cm}^{2}\right)\end{array}$ \\
\hline $35 \mathrm{~nm}$ & 16.4 & 0.695 & 0.41 & 4.6 & 4.6 & 114 \\
\hline $45 \mathrm{~nm}$ & 15.6 & 0.695 & 0.42 & 4.6 & 5.4 & 114 \\
\hline $60 \mathrm{~nm}$ & 15.2 & 0.729 & 0.45 & 5.0 & 8.3 & 186 \\
\hline $65 \mathrm{~nm}$ & 15.3 & 0.784 & 0.53 & 6.3 & 10.4 & 296 \\
\hline $80 \mathrm{~nm}$ & 15.4 & 0.717 & 0.53 & 5.8 & 10.5 & 279 \\
\hline
\end{tabular}
various thickness $\mathrm{C}-\mathrm{TiO}_{2}$ layers a)

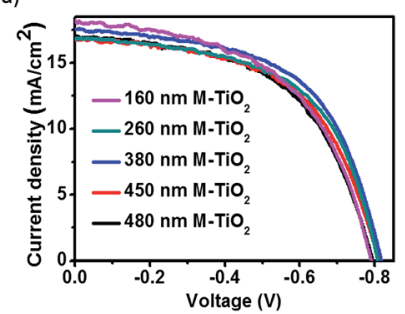

b)

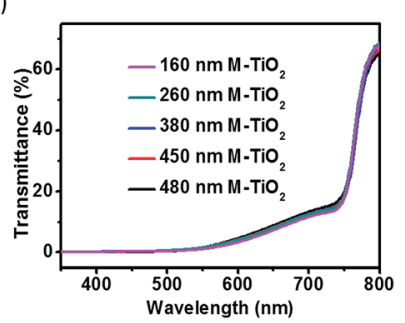

Fig. 3 (a) $J-V$ curves and (b) transmittance curves of perovskites on various thickness $\mathrm{M}-\mathrm{TiO}_{2}$ under illumination.

Table 2 Photovoltaic parameters of the perovskite solar cells with

\begin{tabular}{|c|c|c|c|c|c|c|}
\hline $\mathrm{M}^{-\mathrm{TiO}_{2}}$ & $\begin{array}{l}J_{\mathrm{sc}} \\
\left(\mathrm{mA} \mathrm{cm}^{-2}\right)\end{array}$ & $V_{\mathrm{oc}}(\mathrm{V})$ & $\mathrm{FF}$ & $\eta(\%)$ & $\begin{array}{l}R_{\mathrm{s}} \\
\left(\Omega \mathrm{cm}^{2}\right)\end{array}$ & $\begin{array}{l}R_{\mathrm{sh}} \\
\left(\Omega \mathrm{cm}^{2}\right)\end{array}$ \\
\hline $160 \mathrm{~nm}$ & 18.2 & 0.790 & 0.53 & 7.6 & 10.7 & 340 \\
\hline $260 \mathrm{~nm}$ & 17.0 & 0.794 & 0.55 & 7.4 & 12.7 & 432 \\
\hline $380 \mathrm{~nm}$ & 17.5 & 0.817 & 0.57 & 8.2 & 12.1 & 410 \\
\hline $450 \mathrm{~nm}$ & 16.8 & 0.808 & 0.58 & 7.8 & 16.4 & 577 \\
\hline $480 \mathrm{~nm}$ & 16.7 & 0.810 & 0.56 & 7.6 & 13.4 & 454 \\
\hline
\end{tabular}
various thickness $\mathrm{M}-\mathrm{TiO}_{2}$ layers

thickness increasing though they showed similar absorption (Fig. 3b), which may result from the increasing series resistances. The most efficient device showed an efficiency of $8.2 \%$ with $J_{\mathrm{sc}}$ of $17.5 \mathrm{~mA} \mathrm{~cm}^{-2}, V_{\mathrm{oc}}$ of $0.817 \mathrm{~V}$, FF of 0.57 with a $380 \mathrm{~nm}$ thick $\mathrm{M}$ - $\mathrm{TiO}_{2}$ layer.

Another unfavorable carrier recombination process might happen in $\mathrm{TiO}_{2} /$ graphite contact in the case that perovskite layer was not compact enough. In order to investigate the influence of the $\mathrm{TiO}_{2}$ /graphite contact on device performance, different-coverage perovskites were spin-coated on $\mathrm{M}-\mathrm{TiO}_{2}$ layers. By controlling the concentration of precursor solution, different coverage of perovskite were prepared. The typical topview SEM images of them were shown in Fig. 4. These results suggested that the coverage become higher with the solution

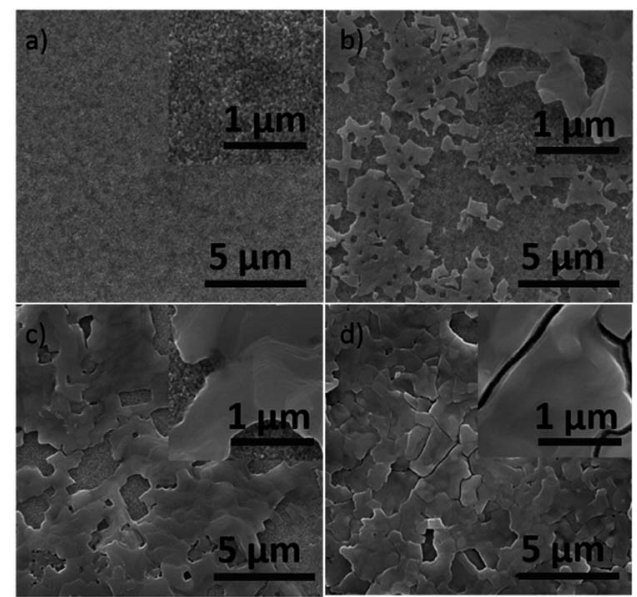

Fig. 4 Typical SEM images of perovskite morphologies on $\mathrm{TiO}_{2}$ surface with different coverages. 
a)

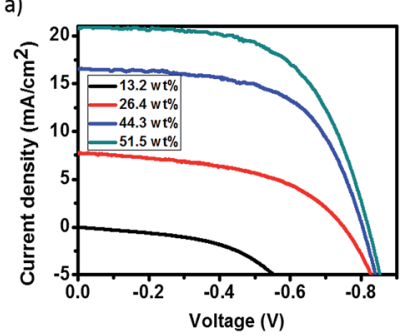

b)

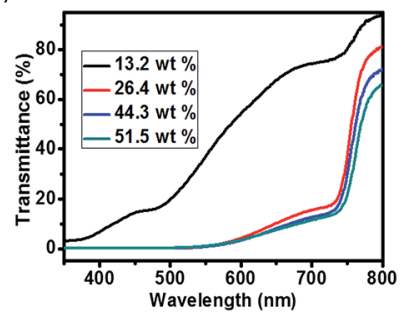

Fig. 5 (a) J-V curves and (b) transmittance curves of perovskites with different coverages under illumination.

concentration increasing. X-ray diffraction (XRD) experiment was carried out to examine the crystal structure of the perovskite material. Fig. $\mathrm{S} 3 \uparrow$ showed the three-dimensional schematic representation and the corresponding XRD pattern. The materials presented a tetragonal perovskite structure with lattice parameters $a=8.825 \AA, b=8.835 \AA, c=11.24 \AA$. The intense diffraction peaks appeared at $14.20^{\circ}, 28.58^{\circ}$, and $43.27^{\circ}$, which could be respectively assigned to (110), (220), (330) diffractions of the tetragonal phase.

The $J-V$ curves under illumination and light transmittance spectra of devices with different coverage perovskite were recorded in Fig. 5, and the detail parameters are presented in Table 3. It can be seen from Fig. 5a that the performance of devices improved a lot with the increase of perovskite coverage. The efficiency of devices increased from almost zero to $2.8 \%$ as the concentration of precursor solution increased from $13.2 \%$ to $26.4 \%$, which resulted from both the increase of light absorption (Fig. 5b) and the improvement of perovskite coverage (Fig. 4). As the concentration of precursor solution further increased, the coverage of perovskite continued to increase, resulting in the improvement of device performances. Since perovskite film was not compact, the uncovered $\mathrm{TiO}_{2}$ came into contact with the graphite electrode. A Schottky junction was formed when $\mathrm{TiO}_{2}$ came into contact with graphite electrodes. We here saw a parallel with the $\mathrm{TiO}_{2} /$ perovskite heterojunction as shown in Fig. 6. To study the effect of $\mathrm{TiO}_{2} /$ graphite contact, a device with graphite electrode printing on pure $\mathrm{TiO}_{2}$ was fabricated. The resulting $J-V$ curves are shown in Fig. S4. $\dagger$ It can be seen that the $J-V$ curve recorded in the dark showed good rectifying performance whereas the $J-V$ curve recorded in the light was almost a straight line, indicating the $\mathrm{TiO}_{2} /$ graphite contact acted as an ohmic contact. This might be due to the increasing surface state densities of $\mathrm{TiO}_{2}$ induced by UV-light, ${ }^{39}$ which made a smaller contact potential difference between $\mathrm{TiO}_{2}$ and graphite. For these reasons, the $\mathrm{TiO}_{2} /$ graphite

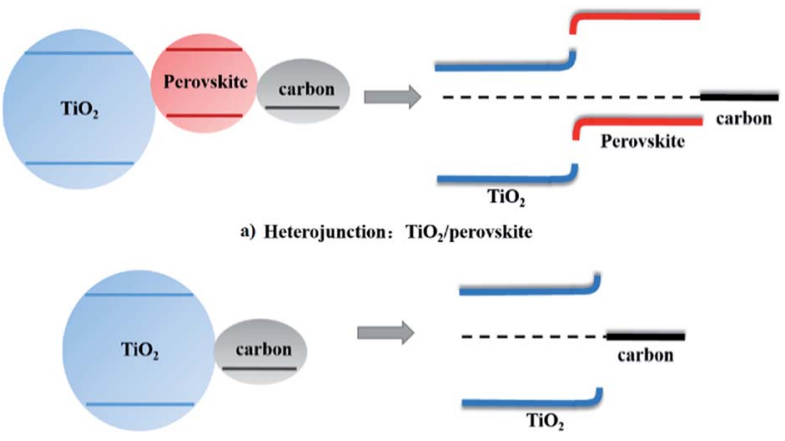

b) Schottky junction: $\mathrm{TiO}_{2} /$ carbon

Fig. 6 Energy band diagrams of (a) $\mathrm{TiO}_{2} /$ perovskite heterojunction and (b) $\mathrm{TiO}_{2}$ /carbon Schottky junction.
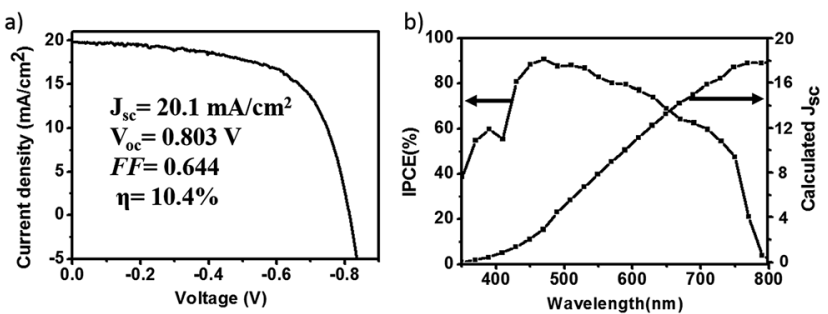

Fig. 7 (a) J-V curves of a best performed device and (b) the corresponding IPCE of the device.

contact was more like an ohmic contact. The parallel resistances of the devices under illumination were calculated as shown in Table 3. They increased from $329 \Omega \mathrm{cm}^{2}$ to $2287 \Omega \mathrm{cm}^{2}$ with the perovskite coverage increasing, leading to larger photovoltages and better performances of the devices. In optimal conditions, a device showed an efficiency of $10.4 \%$ with $J_{\mathrm{sc}}$ of $20.1 \mathrm{~mA} \mathrm{~cm}^{-2}, V_{\text {oc }}$ of $0.803 \mathrm{~V}, \mathrm{FF}$ of 0.644 as presented in Fig. $7 \mathrm{a}$. The monochromatic incident photon-to-electron conversion efficiency (IPCE) data was illustrated in Fig. $7 \mathrm{~b}$ with the highest value up to $90 \%$ at $470 \mathrm{~nm}$. That being said, there are still great potential to improve the device performance, especially the photo-voltage.

The stability of the device was further tested. The stabilizedpower output curve under illumination of the device was measured in Fig. S6, $\uparrow$ showing a steady efficiency of $9.2 \%$ over $400 \mathrm{~s}$. A device was left in ambient atmosphere for 10 days to measure its stability. The $J-V$ curves and photovoltaic parameters were shown in Fig. 8 and Table 4 . The device efficiency dropped to $10.2 \%$ after 10 days, which was comparable with the initial efficiency of $10.3 \%$. Furthermore, we immersed an

Table 3 Photovoltaic parameters of perovskite solar cells with different-coverage perovskites

\begin{tabular}{|c|c|c|c|c|c|}
\hline Precursor concentration & $J_{\mathrm{sc}}\left(\mathrm{mA} \mathrm{cm} \mathrm{cm}^{-2}\right)$ & $V_{\mathrm{oc}}(\mathrm{V})$ & $\mathrm{FF}$ & $\eta(\%)$ & $R_{\mathrm{sh}}\left(\Omega \mathrm{cm}^{2}\right)$ \\
\hline $13.2 \%$ & 0.006 & 0.002 & 0.28 & $3.4 \times 10^{-6}$ & 329 \\
\hline $26.4 \%$ & 7.7 & 0.750 & 0.48 & 2.8 & 500 \\
\hline $51.5 \%$ & 20.1 & 0.820 & 0.60 & 10.3 & 2287 \\
\hline
\end{tabular}




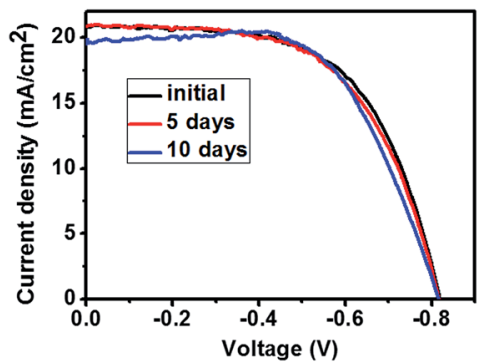

Fig. 8 Stabilities of a perovskite solar cell under ambient atmosphere.

Table 4 Photovoltaic parameters of a perovskite solar cells in ambient atmosphere for different days

\begin{tabular}{lllll}
\hline Days & $J_{\mathrm{sc}}\left(\mathrm{mA} \mathrm{cm}^{-2}\right)$ & $V_{\mathrm{oc}}(\mathrm{V})$ & $\mathrm{FF}$ & $\eta(\%)$ \\
\hline 0 & 20.8 & 0.820 & 0.60 & 10.3 \\
5 & 20.6 & 0.817 & 0.60 & 10.1 \\
10 & 19.4 & 0.821 & 0.64 & 10.2
\end{tabular}

unsealed device in water for 1 minute and tested its performance before and after immersion. Photos of device before and after immersion were shown in Fig. S7. $\dagger$ It can be seen that the perovskite without graphite turned to be yellow, while the one with graphite kept being black. Though the efficiency lowered from the initial $9.72 \%$ to $8.31 \%$, it increased to $8.93 \%$ after 1 day by just leaving it in ambient atmosphere (Fig. S8, Table S3†).

\section{Conclusions}

In conclusion, HTM free perovskite solar cells with low temperature processed graphite electrodes were fabricated and two contact effects on device performances were investigated. It was found that both $\mathrm{FTO} /$ Perovskite and $\mathrm{TiO}_{2} /$ graphite contact could degrade the device performance especially the photovoltage, which could mainly be due to the carrier recombination process introduced by the contacts. By introducing a $65 \mathrm{~nm}$ $\mathrm{C}-\mathrm{TiO}_{2}$ layer and $380 \mathrm{~nm} \mathrm{M}-\mathrm{TiO}_{2}$ layer, the $\mathrm{FTO} /$ perovskite contact was efficiently lowered down, leading an enhancement of the photo-voltage from $0.695 \mathrm{~V}$ to $0.817 \mathrm{~V}$. The $\mathrm{TiO}_{2} /$ graphite contact was decreased by improving the perovskite coverage on $\mathrm{TiO}_{2}$ surface, which helped the photo-voltage increase from almost zero to $0.820 \mathrm{~V}$. Finally, a best efficiency of $10.4 \%$ was obtained. Stability experiments suggested that the devices had excellent stability, which stayed stable in ambient atmosphere for over 10 days. These results indicate that FTO/ perovskite and $\mathrm{TiO}_{2}$ /graphite contacts have important influence on improving the performances of HTM free perovskite solar cells with graphite electrodes, which is fundamental to further enhancing the device's performances.

\section{Acknowledgements}

This work was supported by the Ministry of Science and Technology (Grants 2011CB933002 and 2012CB932702) and National Science Foundation of China (Grants 61306079 and
61671022), and Beijing Municipal Science and Technology Commission (Grants Z171100002017003).

\section{Notes and references}

1 A. Kojima, K. Teshima, Y. Shirai and T. Miyasaka, J. Am. Chem. Soc., 2009, 131, 6050.

2 W. S. Yang, J. H. Noh, N. J. Jeon, Y. C. Kim, S. Ryu, J. Seo and S. I. Seok, Science, 2015, 348, 1234.

3 H. S. Kim, C. R. Lee, J. H. Im, K. B. Lee, T. Moehl, A. Marchioro, S. J. Moon, R. H. Baker, J. H. Yum and J. E. Moser, Sci. Rep., 2012, 2, 591.

4 J. Burschka, N. Pellet, S. J. Moon, R. H. Baker, P. Gao, M. K. Nazeeruddin and M. Gratzel, Nature, 2013, 499, 316.

5 D. Bi, G. Boschloo, S. Schwarzmueller, L. Yang, E. M. J. Johansson and A. Hagfeldt, Nanoscale, 2013, 5, 11686.

6 Y. Zhong, R. Munir, A. H. Balawi, A. D. Sheikh, L. Yu, M.-C. Tang, H. Hu, F. Laquai and A. Amassian, ACS Energy Lett., 2016, 1, 1049.

7 M. Liu, M. B. Johnston and H. J. Snaith, Nature, 2013, 501, 395.

8 H. Zhou, Q. Chen, G. Li, S. Luo, T. B. Song, H. S. Duan, Z. Hong, J. You, Y. Liu and Y. Yang, Science, 2014, 345, 542.

9 D. P. McMeekin, G. Sadoughi, W. Rehman, G. E. Eperon, M. Saliba, M. T. Horantner, A. Haghighirad, N. Sakai, L. Korte, B. Rech, M. B. Johnston, L. M. Herz and H. J. Snaith, Science, 2016, 351, 151.

10 J. H. Heo, S. H. Im, J. H. Noh, T. N. Mandal, C. S. Lim, J. A. Chang, Y. H. Lee, H. J. Kim, A. Sarkar, M. K. Nazeeruddin, M. Grätzel and S. I. Seok, Nat. Photonics, 2013, 7, 486.

11 D. Q. Bi, L. Yang, G. Boschloo, A. Hagfeldt and E. M. Johansson, J. Phys. Chem. Lett., 2013, 4, 1532.

12 S. D. Chavhan, O. Miguel, H. J. Grande, V. G. Pedro, R. S. Sánchez, E. M. Barea, I. M. Seró and T. Z. Ramon, J. Mater. Chem. A, 2014, 2, 12754.

13 J. A. Christians, R. C. Fung and P. V. Kamat, J. Am. Chem. Soc., 2013, 136, 758.

14 J. Li, J. X. Yao, H. R. Xia, W. T. Sun, J. Liu and L. M. Peng, Appl. Phys. Lett., 2015, 107, 1.

15 T. Gatti, S. Casaluci, M. Prato, M. Salerno, F. Di Stasio, A. Ansaldo, E. Menna, A. Di Carlo and F. Bonaccorso, Adv. Funct. Mater., 2016, 26, 7443.

16 A. L. Palma, L. Cinà, S. Pescetelli, A. Agresti, M. Raggio, R. Paolesse, F. Bonaccorso and A. Di Carlo, Nano Energy, 2016, 22, 349.

17 M. Lee, Y. Ko, B. K. Min and Y. Jun, ChemSusChem, 2016, 9, 31.

18 J. Troughton, D. Bryant, K. Wojciechowski, M. J. Carnie, H. Snaith, D. A. Worsley and T. M. Watson, J. Mater. Chem. A, 2015, 3, 9141.

19 J. Deng, L. Qiu, X. Lu, Z. Yang, G. Guan, Z. Zhang and H. Peng, J. Mater. Chem. A, 2015, 3, 21070.

20 L. Etgar, P. Gao, Z. Xue, Q. Peng, A. K. Chandiran, B. Liu, M. K. Nazeeruddin and M. Graetzel, J. Am. Chem. Soc., 2012, 134, 17396. 
21 W. A. Laban and L. Etgar, Energy Environ. Sci., 2013, 6, 3249. 22 S. Aharon, B. E. Cohen and L. Etgar, J. Phys. Chem. C, 2014, 118, 17160.

23 D. Bi, A. M. El-Zohry, A. Hagfeldt and G. Boschloo, ACS Appl. Mater. Interfaces, 2014, 6, 18751.

24 Z. Liu, T. Shi, Z. Tang, B. Sun and G. Liao, Nanoscale, 2016, 8, 7017.

25 H. Chen, X. Zheng, Q. Li, Y. Yang, S. Xiao, C. Hu, Y. Bai, T. Zhang, K. S. Wong and S. Yang, J. Mater. Chem. A, 2016, 4, 12897.

26 Z. Liu, B. Sun, T. Shi, Z. Tang and G. Liao, J. Mater. Chem. A, 2016, 4, 10700.

27 F. Zhang, X. Yang, M. Cheng, W. Wang and L. Sun, Nano Energy, 2016, 20, 108.

28 Z. Ku, Y. Rong, M. Xu, T. Liu and H. Han, Sci. Rep., 2013, 3, 3132.

29 A. Mei, X. Li, L. Liu, Z. Ku, T. Liu, Y. Rong, M. Xu, M. Hu, J. Chen, Y. Yang, M. Gratzel and H. Han, Science, 2014, 345, 295.
30 Y. Rong, Z. Ku, A. Mei, T. Liu, M. Xu, S. Ko, X. Li and H. Han, J. Phys. Chem. Lett., 2014, 5, 2160.

31 L. Liu, A. Mei, T. Liu, P. Jiang, Y. Sheng, L. Zhang and H. Han, J. Am. Chem. Soc., 2015, 137, 1790.

32 C. Y. Chan, Y. Wang, G.-W. Wu and E. Wei-Guang Diau, J. Mater. Chem. A, 2016, 4, 3872.

33 K. Cao, Z. Zuo, J. Cui, Y. Shen, T. Moehl, S. M. Zakeeruddin, M. Grätzel and M. Wang, Nano Energy, 2015, 17, 171.

34 H. Li, K. Cao, J. Cui, S. Liu, X. Qiao, Y. Shen and M. Wang, Nanoscale, 2016, 8, 6379.

35 H. Zhou, Y. Shi, Q. Dong, H. Zhang, Y. Xing, K. Wang, Y. Du and T. Ma, J. Phys. Chem. Lett., 2014, 5, 3241.

36 Y. Yang, J. Xiao, H. Wei, L. Zhu, D. Li, Y. Luo, H. Wu and Q. Meng, RSC Adv., 2014, 4, 52825.

37 H. Wei, J. Xiao, Y. Yang, S. Lv, J. Shi, X. Xu, J. Dong, Y. Luo, D. Li and Q. Meng, Carbon, 2015, 93, 861.

38 J. Shi, J. Dong, S. Lv, Y. Xu, L. Zhu, J. Xiao, X. Xu, H. Wu, D. Li, Y. Luo and Q. Meng, Appl. Phys. Lett., 2014, 104, 063901.

39 T. Leijtens, G. E. Eperon, S. Pathak, A. Abate, M. M. Lee and H. J. Snaith, Nat. Commun., 2013, 4, 2885. 